\title{
Plasma concentrations of retinol in obese children and adolescents: relationship to metabolic syndrome components
}

\author{
Concentrações plasmáticas de retinol em crianças e adolescentes obesos: relação com componentes \\ da síndrome metabólica
}

Concentraciones plasmáticas de retinol en niños y adolescentes obesos: relación con componentes del síndrome metabólico

Márcia Teske , Ana Paula B. Melges², Fabíola Isabel S. de Souza¹, Fernando Luiz A. Fonseca ${ }^{1}$ Roseli Oselka S. Sarni

\section{ABSTRACT}

Objective: To evaluate obese children and adolescents' retinol plasma levels and to correlate them with metabolic syndrome components.

Methods: Cross-sectional study with 61 obese children and adolescents (body mass index $\mathrm{Z}$ score $-\mathrm{ZBMI}>+2$ ). Pubertal development, arterial blood pressure, body weight and height for nutritional classification and waist circumference were obtained. A $15 \mathrm{~mL}$ blood sample was collected (after a 12-hour fasting in a low luminosity room) for retinol determination (cut-off inadequate if $<30 \mu \mathrm{g} / \mathrm{dL}$ ), lipid profile (HDL-c, LDL-c, and triglycerides), oral glucose tolerance test (fasting and 120 minutes) and for high sensitivity $\mathrm{C}$-reactive protein. Spearman correlation and multiple linear regression were used in the statistical analysis.

Results: Mean age was $10.7 \pm 2.7$ years. There was a predominance of male gender 38/61 (62\%) and pre-pubertal 35/61 (57\%) subjects. The average plasmatic retinol was $48.5 \pm 18.6 \mathrm{ug} / \mathrm{dL}$. Retinol deficiency and severe obesity were observed in 6/61 (10\%) and 36/61 (59\%), respectively. Glucose level at 120 minutes was the independent and predictive variable of plasma retinol levels $[\beta=-0.286(95 \% \mathrm{CI}-0.013--0.001)]$.

Conclusions: An independent and inverse association between plasma retinol levels and glucose tolerance was observed, suggesting an important contribution of this vitamin in the morbidities associated to obesity in children and adolescents.
Key-words: vitamin A; obesity; glucose metabolism disorders; child; adolescent.

\section{RESUMO}

Objetivo: Avaliar as concentrações plasmáticas de retinol em crianças e adolescentes obesos e relacioná-las com componentes da síndrome metabólica.

Métodos: Por meio de estudo transversal, avaliaram-se 61 crianças e adolescentes obesos (escore $Z$ do índice de massa corpórea - ZIMC >+2). Obtiveram-se os dados de estadiamento puberal, pressão arterial sistêmica, peso e estatura para classificação da condição nutricional e cintura abdominal. Coletaram-se $15 \mathrm{~mL}$ de sangue (após 12 horas de jejum e em sala de baixa luminosidade) para a dosagem do retinol (ponto de corte inadequado se $<30 \mu \mathrm{g} / \mathrm{dL}$ ), para o perfil lipídico (HDL-c, LDL-c e triglicérides), para o teste de tolerância oral à glicose (jejum e 120 minutos) e para a proteína C-reativa ultrassensível. A correlação de Spearman e a regressão linear múltipla foram utilizadas para a análise estatística.

Resultados: A média de idade das crianças estudadas foi de $10,7 \pm 2,7$ anos, predominando-se o gênero masculino 38/61 (62\%) e os pré-púberes 35/61 (57\%). A média do retinol plasmático foi de $48,5 \pm 18,6 \mathrm{ug} / \mathrm{dL}$. Observaram-se deficiência de retinol e obesidade grave em 6/61 (10\%) e 36/61 (59\%), respectivamente. A glicemia aos 120 minutos foi a variável independente e preditora da concentração plasmática de retinol $[\beta=-0,286($ IC95\% -0,013--0,001)].

Endereço para correspondência:

Roseli Oselka S. Sarni

Rua René Zamlutti, 94, apto. 52 - Vila Mariana

CEP 04116-260 - São Paulo/SP

E-mail: rssarni@uol.com.br

Conflito de interesse: nada a declarar 
Conclusões: Houve associação independente e inversa entre o retinol plasmático e a tolerância à glicose, o que sugere a importância dessa vitamina nas morbidades associadas à obesidade, em crianças e adolescentes.

Palavras-chave: vitamina A; obesidade; transtornos do metabolismo de glucose; criança; adolescente.

\section{RESUMEN}

Objetivo: Evaluar las concentraciones plasmáticas de retinol en niños y adolescentes obesos y relacionarlas con componentes del síndrome metabólico.

Métodos: Mediante estudio transversal, se evaluaron 61 niños y adolescentes obesos (escore $Z$ del índice de masa corpórea-ZIMC >+2). Se obtuvieron datos de estadiamento puberal, presión arterial sistémica, peso y estatura para clasificación de la condición nutricional y cintura abdominal. Se recogieron $15 \mathrm{~mL}$ de sangre (después de 12 horas de ayuno y en sala con baja luminosidad) para verificación de dosis de retinol (punto de corte inadecuado si $<30 \mu \mathrm{g} / \mathrm{dL}$ ), para el perfil lipídico (HDL-c, LDL-c y triglicéridos), para la prueba de tolerancia oral a la glucosa (ayuno y 120 minutos) y para proteína C-reactiva ultrasensible. La correlación de Spearman y la regresión lineal múltiple fueron utilizadas para el análisis estadístico.

Resultados: El promedio de edad de los niños estudiados fue de 10,7 $\pm 2,7$ años, con predominancia del género masculino $38 / 61(62,3 \%)$ y los prepúberes 35/61 (57,4\%). El promedio de retinol plasmático fue de $48,5 \pm 18,6 \mu \mathrm{g} / \mathrm{dL}$. Se observaron deficiencia de retinol y obesidad grave en $6 / 61(9,8 \%)$ y 36/61 (59\%), respectivamente. La glucemia a los 120 minutos fue la variable independiente y predictiva de la concentración plasmática de retinol - $\beta=-0,286$ (IC95\% -0,013; - 0,001).

Conclusiones: Hubo asociación independiente e inversa entre el retinol plasmático y la tolerancia a la glucosa, lo que sugiere la importancia de esa vitamina en las morbilidades asociadas a la obesidad, en niños y adolescentes.

Palabras clave: vitamina A; obesidad; trastornos del metabolismo de glucosa; niño; adolescente.

\section{Introduction}

The increased prevalence of obesity in children and adolescents is epidemic in many countries, including Brazil ${ }^{(1,2)}$. Data from the Household Budget Service of 2008 show a five-fold increase in the frequency of obesity in children from 5 to 9 years of age in the last 20 years $^{(2)}$. In adolescents, excess weight is observed in 21.7 and $19.4 \%$ of boys and girls respectively ${ }^{(2)}$.

Obesity is associated with comorbidities that increase the risk of developing other chronic diseases, such as cardiovascular disease. Insulin resistance and oxidative stress are central mechanisms to explain the morbidities associated with excess weight in the short and long term ${ }^{(3)}$.

Cross-sectional studies conducted in children and adolescents with overweight and obesity reported decreased concentrations of vitamin $A^{(4,5)}$. Factors associated with these findings are the reduction in vitamin A intake (food sources), its sequestration in adipose tissue and its increased use in fighting oxidative stress ${ }^{(4,5)}$.

It has been recently emphasized the importance of retinol in the metabolism of adipose tissue and in insulin resistance ${ }^{(6)}$. Studies with experimental animals have demonstrated a relationship between lower concentrations of retinol, greater adiposity, and higher blood glucose levels ${ }^{(7,8)}$. However, there is still no consensus about this relationship in studies conducted in humans, especially in the pediatric age group $^{(9-11)}$.

This study evaluated the plasma concentrations of retinol in obese children and adolescents, relating them to the components of the metabolic syndrome.

\section{Method}

Through a cross-sectional study, 61 obese children and adolescents were evaluated ( $\mathrm{Z}$ score of body mass index ZBMI $>+2)$, who attended the first consultation between February 2008 and November 2009 in the obesity clinic of the Service of Nutrition at the Department of Pediatrics, School of Medicine of ABC (Faculdade de Medicina do $A B C-F M A B C)$.

The research protocol was approved by the Research Ethics Committee of FMABC. Those responsible for children and adolescents signed an informed consent and the consent for inclusion in the study.

The following patients were excluded from the sample: children and adolescents with $\mathrm{Z}$ score for height/age $(\mathrm{HAZ})<-1.0$; those with obesity secondary to diseases; those using immunosuppressive drugs, corticosteroids, and vitamin supplements containing vitamin $\mathrm{A}$ in the 6 months preceding the collection; patients with acute diseases (infectious or inflammatory) at the time of collection of tests and/or whose legal guardians did not consent to participation in the study. 
For all patients, a standardized questionnaire with demographic and clinical data was administered, and a physical examination and assessment of pubertal stage were performed ${ }^{(12)}$. Measurements of weight and height were obtained for the calculation of anthropometric measures, and the classification of nutritional status according to recommendations of the World Health Organization 2006/2007 $7^{(13)}$. Patients were classified as obese when $\mathrm{ZBMI}>+2$ and with severe obesity when $\mathrm{ZBMI}>+3$. The waist circumference was obtained at the midpoint between the last rib and the higher iliac crest, and it was used to calculate the waist/height ratio. The ratio values greater than 0.5 were considered high ${ }^{(14)}$. Systemic blood pressure was measured with aneroid sphygmomanometer by a single measure. Values above the 95 th percentile were considered high for gender, age, and height ${ }^{(15)}$.

The collection of laboratory exams was performed with the patients fasting for 12 hours, by peripheral venipuncture $(15 \mathrm{~mL}$ of blood) in a room with low light in the Laboratory of Clinical Analysis of FMABC, where the samples were processed and analyzed. Plasma retinol was determined using the HPLC (high-performance-liquid-chromatography) ${ }^{(16)}$ and values lower than $30 \mathrm{mg} / \mathrm{dL}$ were considered inappropriate $(1.05 \mathrm{mmol} / \mathrm{L})^{(17)}$. The lipid profile was evaluated (total cholesterol, HDL-c, LDL-c and triglycerides) by the enzymatic and colorimetric method, and for their classification, the cutoff points proposed by the American Academy of Pediatrics were adopted ${ }^{(18)}$. The ultrasensitive C-reactive protein (US-CRP) was determined by chemiluminescence. We also conducted the oral glucose tolerance test with blood sampling to determine blood glucose (colorimetric method) fasting and 120 minutes after oral overload with maltodex$\operatorname{trin}(75 \mathrm{~g})$. The values at 120 minutes lower than $140 \mathrm{mg} / \mathrm{dL}$ were considered normal; from 140 to $200 \mathrm{mg} / \mathrm{dL}$, were considered as glucose intolerance, and higher than $200 \mathrm{mg} / \mathrm{dL}$, type 2 diabetes ${ }^{(19)}$.

For statistical analysis, we used the Statistical Package for the Social Sciences (SPSS), version 20.0. The Mann-Whitney test and Spearman's correlation were applied to compare continuous variables. For qualitative variables, we used the chi-square test. Regarding the multivariate analysis, we used multiple linear regression (stepwise method). The level of significance was set at $5 \%$.

\section{Results}

The mean age of children was $10.7 \pm 2.7$ years and most patients were male, 38/61 (62.3\%), and pre-pubescent, 35/61 $(57.4 \%)$. There were no differences by gender and pubertal

Table 1 - Characteristics of the study population

\begin{tabular}{lccc}
\hline & & $\mathbf{n}(\%)$ & Measure of central tendency and variation \\
\hline Gender & Male & $38(62)$ & \\
Pubertal stage & Pre-pubertal & $35(57)$ & $3.3(2.0-5.9)^{*}$ \\
Severe Obesity & ZBMI >3 & $36(59)$ & $110.0(80-170)^{*}$ \\
Systolic blood pressure $(\mathrm{mmHg})$ & $>$ P95 & $16(26)$ & $70.0(50-110)^{*}$ \\
Diastolic blood pressure $(\mathrm{mmHg})$ & $>$ P95 & $13(21)$ & $0.6 \pm 0.1^{* *}$ \\
Waist/height ratio $(\mathrm{cm} / \mathrm{cm})$ & $>0.5$ & $61(100)$ & $185 \pm 32^{* *}$ \\
Total Cholesterol $(\mathrm{mg} / \mathrm{dL})$ & High & $30(49)$ & $107 \pm 25^{* *}$ \\
LDL-c $(\mathrm{mg} / \mathrm{dL})$ & High & $9(15)$ & $51(35-64)^{*}$ \\
HDL-c $(\mathrm{mg} / \mathrm{dL})$ & Low & $13(21)$ & $112(31-324)^{*}$ \\
Triglycerides $(\mathrm{mg} / \mathrm{dL})$ & High & $27(44)$ & $93 \pm 11^{* *}$ \\
Fasting glucose $(\mathrm{mg} / \mathrm{dL})$ & $>100$ & $15(25)$ & $105(65-182)^{*}$ \\
Glucose at 120 minutes $(\mathrm{mg} / \mathrm{dL})$ & $>140$ & $5(8)$ & $1.5(0.4-4.0)^{*}$ \\
Retinol $(\mathrm{mg} / \mathrm{dL})$ & $<30$ & $6(10)$ & \\
\hline
\end{tabular}

*Median (minimum; maximum); **mean \pm standard-deviation; ZBMI: Z score of body mass index; P: percentile

Table 2 - Linear regression between retinol concentrations and lipid profile, systemic blood pressure, blood glucose (fasting and 120 minutes), ultrasensitive C-reactive protein, Z score of body mass index and waist/height ratio

\begin{tabular}{lccc}
\hline \multirow{2}{*}{ Model } & Standardized Coefficients & \multirow{2}{*}{ B-value } & \multirow{2}{*}{$\mathbf{9 5 \%} \mathbf{C l}$} \\
\cline { 2 - 4 } Glucose at 120 minutes $(\mathrm{mg} / \mathrm{dL})$ & -0.286 & 0.026 & $-0.013--0.001$ \\
\hline
\end{tabular}

Dependent variable: retinol; variables excluded from the model: LDL-C, HDL-c, triglycerides, fasting glucose, waist/height ratio, ZBMI, US-CRP, blood pressure (systolic and diastolic) 
stage for the general variables, for retinol concentrations, and for the components of metabolic syndrome (data not shown).

Severe obesity was observed in 36/61 (59\%) and all patients presented waist/height $>0.5$. Associated morbidities were observed with high frequency (Table 1). As for the oral glucose tolerance test, it was verified that 5/61 (8.2\%) were intolerant (values at 120 minutes above $140 \mathrm{mg} / \mathrm{dL}$ ). No patient had glucose at 120 minutes higher than $200 \mathrm{mg} / \mathrm{dL}$, which characterizes type 2 diabetes.

The mean concentrations of retinol were $48.5 \pm 18.6 \mathrm{ug} / \mathrm{dL}$ and inadequate values were observed in $6 / 61$ (9.8\%) of the sample (Table 1). Retinol values were directly associated with age $(r=0.298)$, triglycerides $(r=0.256)$, and HDL-c $(r=0.304)$, and inversely with blood glucose at 120 minutes $(r=-0.336)$. By means of multivariate analysis, it was observed that glucose at 120 minutes was the predictor and independent variable of the concentration of retinol (Table 2).

\section{Discussion}

The present study described the inverse and independent association between the plasma retinol concentrations and glucose at 120 minutes (glucose intolerance) in obese children and adolescents. Several authors have described the relationship between retinol deficiency and hyperglycemia in experimental models ${ }^{(6,20)}$. However, there is no consensus about this relationship in humans (7,9-11). $^{(1)}$

Inadequate concentrations of retinol $(<30 \mathrm{ug} / \mathrm{dL})$ were observed in $9.8 \%$ of the assessed population. A similar result was described by Valente da Silva et al $^{(21)}$ in a study involving 471 children and adolescents from Rio de Janeiro. In a study by Sarni $e t a l^{(5)}$, a higher frequency of retinol deficiency in obese preschoolers was found (18.2\%). The children and adolescents assessed presented a high percentage of severe obesity. There was also a high frequency of associated morbidities, such as changes in fasting glucose and dyslipidemia, despite the low age (10.7 \pm 2.7 years) of patients. Dyslipidemia associated with obesity, whose central mechanism is insulin resistance, is characterized by increased levels of triglycerides, decreased levels of HDL-c, and abnormal composition of LDL-c, with a higher proportion of small, dense particles ${ }^{(18)}$. The association between micronutrient deficiencies and obesity is another risk factor for the development of noncommunicable chronic diseases in the future ${ }^{(22)}$.

Vitamin A can be found in the organism under several forms: the circulating form is retinol, retinol esters are the form of deposit; retinal and retinoic acid are the biologically active forms. It is difficult to perform the measurement of the active forms of retinol because they are very labile and occur in low concentrations in tissues. To serve its functions, retinol binds to specific groups of receptors (RARs - retinoic acid receptors e RXRs - retinoid X receptors) present in various tissues ${ }^{(23)}$.

Stored retinol, its active forms, and enzymes related to its metabolism and transport can be found in the adipose tissue $^{(23)}$. Studies have sought to better understand the relationship between retinol, obesity, and insulin resistance. However, the results are controversial in humans ${ }^{(7,9-11)}$.

Several hypotheses have been raised in experimental studies. The first relates to the involvement of retinoic acid in the proper functioning of the islets of Langerhans ${ }^{(8)}$. The second refers to the role of retinol in modulating circulating levels of leptin (adipokine that acts in the control of satiety) and improving insulin resistance ${ }^{(24)}$. A diet supplemented with vitamin A was related to lower expression of the leptin gene in rodents ${ }^{(25)}$. The third hypothesis involves the action of vitamin $\mathrm{A}$ on differentiation and metabolism of the adipose tissue. Animals subjected to diet without retinol evolve with growth impairment and greater adiposity. The supplemental retinol or retinoic acid, in turn, is related to reduced fat mass and improved insulin sensitivity ${ }^{(26,27)}$.

In this study, there was no relationship between obesity and retinol concentrations, which were associated only with glucose at 120 minutes. Other studies with similar age range show conflicting results ${ }^{(4,5,11)}$. Long-term clinical trials with a larger number of subjects included (with and without retinol deficiency), using other measures of body composition, may contribute to better understand this relationship in humans.

A fourth hypothesis in this context involves the role of RBP-4 (retinol binding protein 4) in obesity and glucose intolerance. RBP-4 is a protein that transports retinol and is produced predominantly in the liver. However, it can also be considered an adipokine in situations such as insulin resistance ${ }^{(28)}$. In an interesting study ${ }^{(29)}$, the authors found that a group of mice with insulin resistance (knockout for glucose 4 transporter- GLUT4) showed mRNA expression of RBP-4 2.5 times higher compared to controls and that the administration of rosiglitazone (drug that improves insulin sensitivity) reduced the concentrations of RBP-4. The administration of RBP-4 in normal mice, in turn, led to insulin resistance. The authors concluded that adipocytes can release RBP- 4 in the circulation as a sign of glucose intolerance and the treatment of animals with agents that enhance insulin sensitivity may lead to reduced concentrations of RBP- 4 and 
vice versa ${ }^{(29)}$. There are studies in children and adolescents suggesting that RBP-4 can be considered one of the factors related to the morbidities in obesity ${ }^{(11,28)}$.

In the present research, the measurement of RBP-4 was not performed, making it impossible to compare the results with others. There is a current proposal for plasma concentrations of retinol to be considered together with those of RBP-4 through the retinol: RPB-4 ratio. Low values of this ratio are more associated with glucose intolerance than the values of RBP-4 isolated ${ }^{(30)}$. In our setting, further studies are needed to assess the retinol:RPB- 4 ratio and glucose

\section{References}

1. Ogden CL, Carroll MD, Kit BK, Flegal KM. Prevalence of obesity in the United States, 2009-2010. NCHS Data Brief 2012;82:1-8.

2. Brasil - Ministério do Planejamento, Orçamento e Gestão - Instituto Brasileiro de Geografia e Estatística. Pesquisa de Orçamentos Familiares 2008-2009: antropometria e estado nutricional de crianças, adolescentes e adultos no Brasil. Rio de Janeiro: IBGE; 2010.

3. Vazzana N, Santilli F, Sestili S, Cuccurullo C, Davi G. Determinants of increased cardiovascular disease in obesity and metabolic syndrome. Curr Med Chem 2011;18:5267-80.

4. Strauss RS. Comparison of serum concentrations of alpha-tocopherol and beta-carotene in a cross-sectional sample of obese and nonobese children (NHANES III). National Health and Nutrition Examination Survey. J Pediatr 1999;134:160-5.

5. Sarni RO, Souza FI, Ramalho RA, Schoeps DO, Kochi C, Catherino P et al. Serum retinol and total carotene concentrations in obese pre-school children. Med Sci Monit 2005;11:CR510-4.

6. Matthews KA, Rhoten WB, Driscoll HK, Chertow BS. Vitamin A deficiency impairs fetal islet development and causes subsequent glucose intolerance in adult rats. J Nutr 2004;134:1958-63.

7. Krempf M, Ranganathan S, Ritz P, Morin M, Charbonnel B. Plasma vitamin A and $E$ in type 1 (insulin-dependent) and type 2 (non-insulin-dependent) adult diabetic patients. Int J Vitam Nutr Res 1991;61:38-42.

8. Hachisuka $H$, Uno $H$. Effects of retinoic acid on the epidermal Langerhans cells and beta-glucuronidase activity in macaque skin. Am J Dermatopathol 1987;9:316-23.

9. Tavridou A, Unwin NC, Laker MF, White M, Alberti KG. Serum concentrations of vitamins A and $E$ in impaired glucose tolerance. Clin Chim Acta 1997;266:129-40.

10. Aasheim ET, Bøhmer T. Low preoperative vitamin levels in morbidly obese patients: a role of systemic inflammation? Surg Obes Relat Dis 2008;4:779-80.

11. Botella-Carretero JI, Balsa JA, Vázquez C, Peromingo R, Díaz-Enriquez M, Escobar-Morreale HF. Retinol and alpha-tocopherol in morbid obesity and nonalcoholic fatty liver disease. Obes Surg 2010;20:69-76.

12. Marshall WA, Tanner JM. Growth and physiological development during adolescence. Annu Rev Med 1968;19:283-300.

13. de Onis M, Onyango AW, Borghi E, Siyam A, Nishida C, Siekmann J. Development of a WHO growth reference for school-aged children and adolescents. Bull World Health Organ 2007;85:660-7.

14. Mushtaq MU, Gull S, Abdullah HM, Shahid U, Shad MA, Akram J. Waist circunference, waist-hip ratio and waist-height ratio percentiles and central obesity among Pakistani children aged five to twelve years. BMC Pediatr 2011;11:105.

15. National High Blood Pressure Education Program Working Group on High Blood Pressure in Children and Adolescents. The fourth report on the diagnosis, evaluation, and treatment of high blood pressure in children and adolescents. Pediatrics 2004;114 (Suppl 2):555-76. intolerance in situations like that observed in Brazil - high percentage of obesity ${ }^{(2)}$ and vitamin A deficiency ${ }^{(5)}$, especially in pre-school children.

The inverse and independent association between serum retinol and glucose tolerance suggests the importance of the participation of this vitamin in morbidities associated with obesity in children and adolescents. Nutritional education strategies aiming at the adequate intake of energy, macro and micronutrients, especially those with antioxidant properties, should be implemented in overweight individuals, with the goal of reducing future associated morbidities.

16. Nierenberg DW, Lester DC. Determination of vitamins $A$ and $E$ in serum and plasma using a simplified clarification method and high-performance liquid chromatography. J Chromatogr 1985;345:275-84.

17. Brasil - Ministério da Saúde - Centro Brasileiro de Análise e Planejamento. Pesquisa Nacional de Demografia e Saúde da Criança e da Mulher - PNDS 2006. Brasília: Ministério da Saúde; 2009.

18. Daniels SR, Greer FR; Committee on Nutrition. Lipid screening and cardiovascular health in childhood. Pediatrics 2008;122:198-208.

19. Kim G, Caprio S. The $9^{\text {th }}$ Annual World Congress on the Insulin Resistance Syndrome Pediatric Insulin Resistance. Los Angeles, CA. (November 3-5, 2011). Pediatr Endocrinol Rev 2012;9:682-4.

20. Rhee EJ, Plutzky J. Retinoid metabolism and diabetes mellitus. Diabetes Metab J 2012;36:167-80.

21. de Souza Valente da Silva L, Valeria da Veiga G, Ramalho RA. Association of serum concentrations of retinol and carotenoids with overweight in children and adolescents. Nutrition 2007;23:392-7.

22. Aeberli I, Biebinger R, Lehmann R, L'allemand D, Spinas GA, Zimmermann $M B$. Serum retinol-binding protein 4 concentration and its ratio to serum retinol are associated with obesity and metabolic syndrome components in children. $\mathrm{J}$ Clin Endocrinol Metab 2007;92:4359-65.

23. Janke J, Engeli S, Boschmann M, Adams F, Böhnke J, Luft FC et al. Retinolbinding protein 4 in human obesity. Diabetes 2006;55:2805-10.

24. Felipe F, Bonet ML, Ribot J, Palou A. Modulation of resistin expression by retinoic acid and vitamin A status. Diabetes 2004;53:882-9.

25. Canas JA, Damaso L, Altomare A, Killen K, Hossain J, Balagopal PB. Insulin resistance and adiposity in relation to serum $\beta$-carotene levels. J Pediatr 2012;161:58-64.e1-2.

26. Wallström P, Wirfält E, Lahmann PH, Gullberg B, Janzon L, Berglund G. Serum concentrations of beta-carotene and alpha-tocopherol are associated with diet, smoking, and general and central adiposity. Am J Clin Nutr 2001;73:777-85.

27. Alcântara-Neto OD, Silva RC, Assis AM, Pinto Ede J. Factors associated with dyslipidemia in children and adolescents enrolled in public schools of Salvador, Bahia. Rev Bras Epidemiol 2012;15:335-45.

28. Rinaldi AE, Nogueira PC, Riyuzo MC, Olbrich-Neto J, Gabriel GF, Macedo CS et al. Prevalence of elevated blood pressure in children and adolescents attending highschool. Rev Paul Pediatr 2012;30:79-86.

29. Silva LS, Veiga GV, Ramalho RA. Association of serum concentrations of retinol and carotenoids with overweight in children and adolescents. Nutrition 2007;23:392-7.

30. García OP, Ronquillo D, Caamaño Mdel C, Camacho M, Long KZ, Rosado JL. Zinc, vitamin $A$, and vitamin $C$ status are associated with leptin concentrations and obesity in Mexican women: results from a cross-sectional study. Nutr Metab (Lond) 2012;9:59. 